I Universidade Nova de Lisboa, Instituto de Etnomusicologia

(INET-MD), Lisboa, Portugal; e Centre de Recherche en Ethnomusicologie

(CREM-LESC), Université Paris Ouest Nanterre, Paris, França

filibb@gmail.com

Filippo Bonini Baraldi

\title{
COMO ESTUDAR A EMOÇÃO MUSICAL? PROPOSTAS METODOLÓGICAS \\ A PARTIR DE PESOUISA JUNTO AOS CIGANOS DA TRANSILVÂNIA (ROMÊNIA)
}

\section{INTRODUÇÃO: POR UMA ANTROPOLOGIA DA EMOÇÃO MUSICAL}

Por que a música nos toca, às vezes até fazer chorar? De alcance muito geral, essa indagação transforma-se em enigma de rara complexidade quando se trata de fazer dela um objeto científico. Pode-se realmente entender o poder emocional da música? Estariam adaptadas as ferramentas da ciência? Ademais, que métodos poderiam ser usados? Em que pesem o crescente avanço das ciências cognitivas e o impulso de inúmeras pesquisas sobre as emoções (entre outros, Damasio I995; Ekman et al., 2003; Lewis et al., 2008), essas são algumas perguntas ainda amplamente não respondidas.

A emoção musical depende de um número potencialmente infinito de variáveis (ancoragem cultural, história de vida pessoal, contexto de performance, estado psicológico do momento etc.) e certamente não se resume em explicação única. Esse tema de pesquisa, contudo, constitui um formidável campo para a compreensão do homem em suas dimensões psicológica e social. A música envolve processos internos, no corpo e no cérebro, que podemos chamar de emoções ou sentimentos, como bem observaram Damasio (I995) e, antes dele, Spinoza (I954). ${ }^{\mathrm{I}}$ A música põe igualmente em marcha complexos processos sociais e, em muitas culturas, constitui um meio privilegiado para a expressão, a comunicação e a ritualização das emoções - desta vez entendidas como "artefatos culturais" (Geertz, I973). 
Do ponto de vista da etnomusicologia, uma hipótese fundamental explica a importância desse tema de pesquisa: a emoção musical pode ser estudada em qualquer contexto cultural. A esse respeito, Molino e Nattiez (2007: 372) constatam que "a importância dos afetos na música [...] parece universal, e tanto para McAllester (I97I) quanto para vários etnomusicólogos, a criação de uma heigthened experience constituiria um dos raros universais aceitáveis". Segundo Becker (200I), o arousal (termo que poderíamos traduzir por "excitação fisiológica"), intimamente ligado à experiência emocional, seria uma resposta universal à música. Os pais da disciplina não hesitaram em assinalá-lo: em sua tentativa de determinação das funções gerais da música, Merriam (I964) refere "expressão emocional", e Blacking (I973) concorda com o povo venda, da África do Sul, que considera a música essencial para a sobrevivência dos sentimentos humanos. Seeger (2004: 62, tradução minha), em um parágrafo curto no qual compara as "ideias sobre a origem e a natureza da música" junto aos Kaluli de Papua-Nova Guiné, aos Suyá do Brasil e aos gregos antigos, observa que "em todas as três tradições musicais, a música propicia uma experiência emocional de considerável força. As canções dos Kaluli provocam tristeza e raiva, o canto dos Suyá provoca tristeza em alguns e euforia nos demais, e para alguns gregos da Antiguidade a música trazia a aproximação gradual à beleza absoluta". Ora, embora existam contraexemplos (ver Cler, 2010), a meu ver, eles não bastam para reduzir a grande generalidade, senão a universalidade, do fenômeno afetivo na música.

Ainda que os etnomusicólogos não ignorem a estreita ligação da música com os processos emocionais, eles todavia deixaram o tema de lado durante quase meio século e, salvo algumas exceções (Rouget, I980; Feld, I982; Wolf, 200I; Becker, 2004; Benamou, 20I0), o estudo da emoção musical permaneceu confinado à filosofia (Budd, I985), à musicologia (Meyer, I956) e às ciências cognitivas (Sloboda \& Juslin, 20I0). ${ }^{2}$ Como consequência, as pesquisas científicas nesse domínio concentram-se quase unicamente na música clássica ocidental, no modo de performance a ela associado (a forma concerto), facilmente reproduzível em laboratório (o modelo composer-performer-listener, ver Kendall \& Carterette, I990), e em uma concepção muito etnocêntrica da pessoa e das emoções (ver a crítica de Surrallès, 2000).

Em que pesem as descobertas referentes a processos emocionais low level (no cérebro), os cognitivistas desenvolveram uma opinião bastante crítica acerca do impacto de duas décadas de experimentos relativos à emoção musical, caracterizados por resultados muitas vezes contraditórios. ${ }^{3}$ Uma das causas desse impasse seria sem dúvida a pouca atenção dada aos processos da emoção em outras sociedades e outros contextos de performance. Cada grupo social inventa maneiras diferentes para gerenciar, manipular e fazer uso desse poder universal da música em despertar ou acompanhar as emoções: por isso se torna necessário descrever como é concebida e vivida a emoção 
musical em outras sociedades. No longo prazo, cruzar os dados oriundos de diferentes contextos culturais permitirá identificar os processos psicológicos e sociais recorrentes, quiçá universais, da emoção musical.

É duplo o objetivo deste artigo. ${ }^{4}$ Em primeiro lugar, tratar-se-á de analisar as relações entre emoções e música em um contexto cultural bem delimitado, a saber, aquele de uma comunidade cigana da Transilvânia (Romênia). A partir dessa descrição etnográfica, o segundo objetivo consistirá em extrapolar informações que possam ser comparadas com dados provenientes de outras sociedades. Todavia, como estudar a emoção musical fora do laboratório, nas performances reais que ocorrem ao redor do planeta? Como obter, a partir da etnografia da performance, informações que permitam comparar a emoção musical em diversas culturas? O que comparar exatamente? Tais indagações, de ordem fundamentalmente metodológica, estão no cerne dos parágrafos a seguir.

\section{ESCOLHAS METODOLÓGICAS PARA O ESTUDO DA EMOÇÃO MUSICAL IN LOCO}

Antes de adentrar a descrição das escolhas metodológicas relativas a meu estudo de campo, cabe ainda precisar o sentido em que entendo a expressão "emoção musical".

Para identificar as emoções provocadas pela música e distingui-las entre si, os neurocientistas observam as transformações, no corpo e no cérebro, de vários parâmetros fisiológicos (ritmo cardíaco, condutividade da pele etc., ver Peretz \& Zatorre, 2003), muito amiúde com a ajuda de tecnologias sofisticadas. Por sua vez, os psicólogos baseiam-se em rigorosas e controladas experiências perceptivas, seguidas pelo tratamento estatístico das respostas verbais dos sujeitos (Sloboda \& Juslin, 2010). Nesses campos científicos, a expressão "emoção musical" (em inglês musical emotion) é geralmente usada no sentido de "emoções expressas na música", "emoções percebidas na música" ou "emoções induzidas pela música” (Juslin \& Västfjäll, 2008; Sloboda \& Juslin, 20ıo).

Do ponto de vista da etnomusicologia de campo, principalmente focada em performances, o problema da emoção musical está posto em qualquer situação na qual música e emoções "andem juntas" (Bonini Baraldi, 20I3). Essa expressão sublinha a simultaneidade de espaço e tempo entre ações musicais e comportamentos emocionais, sem assumir de antemão uma relação causal entre ambos. De fato, ao se observar um comportamento passível de ser qualificado como emocional concomitantemente a uma prática musical, não se pode dizer a priori que se trate de uma "resposta" à música. Em uma perspectiva antropológica, o tipo de relação entre as diversas ações de uma performance neste caso, tocar música e expressar emoções - constitui o objetivo da análise, e não um axioma inicial.

Ainda que fosse possível, não sem inúmeros problemas de ordem metodológica e ética, utilizar no campo tecnologias sofisticadas no intuito de 
detectar emoções induzidas pela música (Fritz et al., 2009; Egermann et al., 20I5), o antropólogo usa antes de mais nada seu mero olhar (e ouvidos). Como então poderia ele afirmar que um comportamento seria revelador de uma emoção determinada? Como distingui-lo de outro que não o seria? "Localizar" as experiências emocionais constitui, do ponto de vista da etnomusicologia, um problema metodológico de suma importância que diferencia a pesquisa sobre a emoção musical daquela sobre o transe, um tema clássico da etnomusicologia contemporânea (Rouget, I980; Becker, 2004). De fato, o transe é prática circunscrita no tempo e muitas vezes manifesta de forma aberta, quiçá espetacular, conquanto a emoção possa evoluir em um continuum temporal e ser vivida de modo intenso, porém, sem estar acompanhada de sinais evidentes de expressão. A solução para esse problema metodológico só pode ser encontrada ao se compartilhar a vida dos protagonistas. É pelo aprendizado dos códigos expressivos que se pode dizer se um comportamento, uma ação ou um gesto são reveladores de uma determinada vivência emocional. É o trabalho de campo que permite discernir as categorias do sentir, colocá-las em correspondência com aquelas do pesquisador e traduzi-las para que o leitor possa entendê-las ou mesmo experimentá-las (Leavitt, I996).

Portanto, embora um prolongado trabalho de campo constitua a condição sine qua non de qualquer discurso antropológico sobre a emoção musical, são igualmente necessárias outras escolhas metodológicas para se delimitar um objeto de estudo que se pode revelar amplo demais. Uma maneira de circunscrever o problema equivale a se concentrar em um tipo de expressão que, em dado contexto cultural, pareça mais recorrente e importante que outros tipos. Em minha pesquisa sobre a emoção musical na Transilvânia, adotei o seguinte critério metodológico: focar a atenção nos "prantos musicais". Designo assim situações em que lágrimas e música andam juntas - independentemente de quem chora e de quem produz sons - distinguindo-as, desse modo, das circunstâncias em que se chora, porém sem música.

Diversas razões motivaram essa escolha. Em primeiro lugar, os prantos constituem um sinal emocional de fácil observação, não exigindo nenhuma técnica além do olhar. Ainda que isso não resolva o problema da compreensão das emoções subjacentes (o que sentimos), focalizar-se nos prantos igualmente oferece a vantagem de circunscrever a emoção no tempo (quando sentimos) e no espaço (quem sente). Ademais, junto aos ciganos ${ }^{5}$ da Transilvânia, não é raro chorar com música. Por fim, concentrar-se nos prantos traz vantagem adicional: ir ao encontro do ponto de vista local, segundo o qual, "música boa é aquela que faz chorar". Um bom músico tem o poder de fazer seu público chorar, de "lhe partir o coração" (să-i spargă inima), podendo, enquanto chora, apreciar um bom bailarino, um bom cantor ou um bom instrumentista. Assim, nesse contexto sociocultural, os prantos musicais revelam algo fundamental. Trata-se precisamente daquilo que a análise etnográfica pretende descobrir. 


\section{TRÊS CONTEXTOS DE PRANTOS MUSICAIS JUNTO AOS CIGANOS DA TRANSILVÂNIA (ROMÊNIA)}

Minhas pesquisas de campo concentraram-se em um pequeno povoado rural da Transilvânia Central (Romênia), Ceuaș, onde convivem aproximadamente 700 campesinos húngaros (a Transilvânia fazia parte da Aústria-Hungria) e 400 ciganos. Estes últimos vivem em um morro adjacente, em um bairro afastado chamado de țigănie ("o bairro cigano", ver Figura I). Geralmente profissionais, os músicos ciganos tocam em diversos contextos, tais como casamentos, batismos, funerais, banquetes, concertos ou festivais folclóricos. Do ponto de vista das relações entre música e emoção, essas performances podem ser classificadas segundo três grandes categorias: I) o serviço profissional, 2) as festas espontâneas no bairro cigano, e 3) os funerais. A observação e a comparação de diversas festas de caráter semelhante permitiram determinar as "regras" que regem cada uma dessas três categorias. ${ }^{6}$

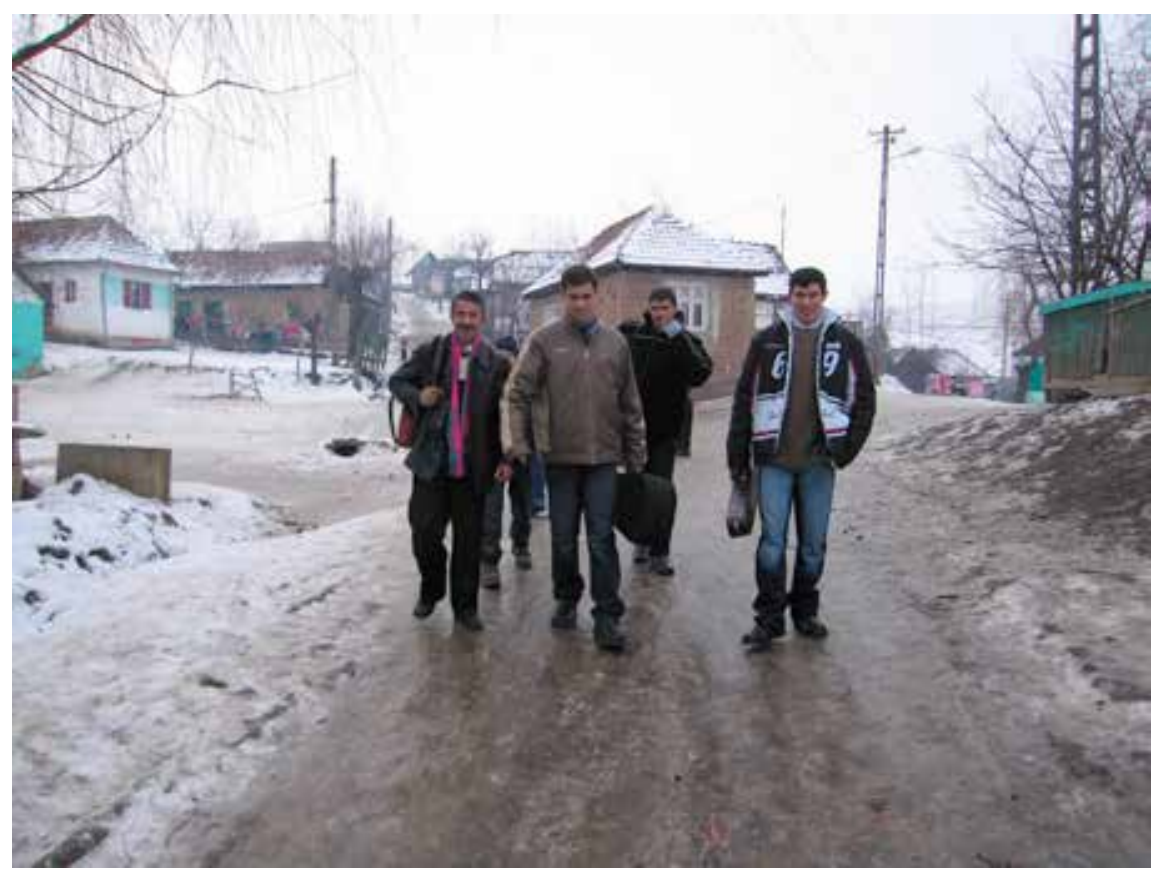

Figura I

Músicos de Ceauș descem do bairro cigano para tocar, $2005^{7}$ 


\section{O serviço profissional}

Para referir-se às situações em que tocam mediante remuneração, como ocorre nas grandes festas de matrimônio, os músicos ciganos usam o termo "serviço" (serviciu). Essa palavra dá conta do fato de que, nesses contextos, tudo deve ser feito para satisfazer os clientes: fazê-los dançar, fazê-los cantar ou fazê-los chorar. Quando está em serviço, o músico profissional tem como preocupação o respeito de uma prescrição fundamental: "permanecer no seu lugar" (a sta la locul său). Trata-se aqui de um duplo rigor que remete tanto à moral quanto ao comportamento. Há que respeitar seus compromissos e ao mesmo tempo comportar-se bem, ou seja, cumprir o contrato sem se deixar arrastar pelos excessos da festa. De fato, quer se trate de um casamento cigano, de um banquete húngaro ou de um baile romeno, a posição do músico cigano permanece globalmente a mesma: "está construindo uma festa que não é a sua" (Lortat-Jacob, I994: I07).

Fica clara e explícita a consequência dessa ética profissional: a música tem que "funcionar" (merge). Pouco importa tocar uma ou outra melodia, tal dança em vez de outra, conquanto "funcione". A escolha do repertório - e a maneira de interpretá-lo - ocorre de forma pragmática: tal ou qual melodia "funciona" se provocar algum efeito sobre o público. Não se procura aqui um funcionamento global e abstrato da música; o efeito de uma melodia ancora-se no presente, segundo as necessidades, e o repertório se constrói no hic et nunc da performance. Em um jantar coletivo no salão de festa, quando o público está sentado ao redor de uma mesa, a música "funciona" quando é discreta, para que os convidados possam cantar e conversar. Por outro lado, nas festas de casamento ou nos bailes do bairro cigano, se ninguém dança é porque a música não "funciona". E no final das festas transilvanas as lágrimas dos convidados, bem visíveis ou mais íntimas, são o efeito almejado.

Nesse momento, geralmente coincidente com a chegada dos primeiros raios de sol, a festa mobiliza sentimentos de tonalidade agridoce (Demeuldre, 2004). As melodias de jale ("de aflição"), lentas e em ritmo descompassado, ocupam esse espaço-tempo matutino - que antecipa a retomada iminente do trabalho e da dura vida cotidiana - remetendo às lembranças da juventude, à tristeza de um amor perdido, à nostalgia de um parente que vive no exterior. As letras das canções revelam a textura emocional que se busca: em meio aos ciganos, a jale ("tristeza, aflição") emerge de versos inspirados em fatos que evocam a prisão, o necaz ("desgraça"), o sofrimento da separação do ser amado ou apelos a Deus para chamar a sorte ([t]bact) e a saúde ([t]sasté). Junto aos húngaros, no final da festa, cantam-se principalmente textos de poetas nacionais, com histórias de soldados e de amor, mais austeras e metafóricas. Todavia, quer se trate de um casamento cigano ou de um banquete húngaro, o propósito da mobilização das emoções durante esse tipo de reunião é idêntico. Graças à possibilidade de comunicar e compartilhar vivências subjetivas, rea- 
liza-se tranquilizadora tomada de consciência: vivemos entre semelhantes, nossos vizinhos são como nós, juntos formamos uma "comunidade de afetos" (Pasqualino, 2005).

Nesses momentos finais, os músicos usam sutis estratégias para despertar as emoções dos seus clientes, em algumas ocasiões até fazê-los chorar. Ainda que ao longo do "serviço" ocupem um espaço separado, na fase final da festa, eles "entram em meio às mesas" (a merge între mese) para tocar ao pé do ouvido dos convidados sentados em pequenos grupos (ver Figura 2). É nesse momento que os músicos tocam as melodias prediletas ou "pessoais" de cada cliente. Aqueles que desfrutam desse toque personalizado têm a certeza de viver um momento privilegiado e agradecem aos músicos com gorjetas. "Assim que o vejo, já sei qual é sua canção!”, garante Csángáló, um dos melhores músicos do povoado, revelando assim que a atividade profissional dos músicos ciganos se baseia em um conhecimento particularizado, até individualizado, dos hábitos e gostos dos convidados. A bem da verdade, os músicos que tocam na região desde a infância conhecem não só os nomes dos habitantes dos povoados vizinhos, o número de cavalos que possuem e a localização de suas terras, mas igualmente o que cada um deles gosta de dançar ou cantar.

Em virtude da proximidade que se cria entre músicos e convidados e graças aos conhecimentos que os primeiros têm sobre os segundos, é um efeito de "ressonância" entre música e estados da alma que se busca na fase final das festas. Tal efeito é veiculado pela melodia "pessoal" - uma síntese musical de um conjunto de preferências estéticas, de lembranças conscientes e de memórias implícitas - que faz vibrar com maior amplitude uma pessoa específica, sintonizando-a com sua "frequência natural" e deixando-a, por assim dizer, mais vulnerável. São essas afinidades entre formas musicais e formas do espírito dos clientes que os músicos buscam ativar (rentabilidade para o presente) e memorizar (investimento para o futuro). "O cigano é como o diabo" (Tiganu'e ca dracu'), costuma-se dizer em Ceuaș para indicar essa capacidade do músico profissional de lembrar das melodias "pessoais" de cada um de seus clientes, de se colocar no lugar de outrem para entender o que sente e de estabelecer uma relação de empatia com seus clientes (ver Figura 2).

\section{As festas no bairro cigano}

O segundo contexto em que prantos e música caminham juntos consiste em um conjunto de performances mais íntimas e espontâneas, as quais ocorrem unicamente no bairro cigano. É o caso das "festas" ([t]chef) que os músicos organizam entre si depois de ter tocado em um matrimônio (Bonini Baraldi, 20ıoa) ou ainda das pequenas festas familiares. Nestes casos, os músicos não são contratados nem remunerados; não têm, portanto, deveres profissionais perante seus ouvintes e tocam para si próprios, em círculo, voltados uns para os outros. Ao contrário das situações profissionais, em que o chefe violonista tem 
a responsabilidade de conduzir o grupo e escolher o repertório em função das vontades e dos gostos dos convidados, a relação entre os músicos é liberada de qualquer hierarquia. Cada um pode tocar o que quiser, quando quiser, as gravatas se afrouxam, as posturas são descontraídas, e o consumo de álcool está liberado (ver Figura 3).

Nestas festas, não é raro ver os músicos chorar, ao passo que os ouvintes permanecem à margem dessa expressão emocional. Os ciganos usam a palavra supărare para explicar seu estado emocional quando choram ao tocar. Esse termo indica uma mistura de tristeza, aflição e amargura, assim como de irritação, contrariedade e raiva. A crise de supărare é sempre transitória, com início e fim bem delimitados, podendo repetir-se várias vezes e a qualquer momento. É preciso que seja breve e se conclua rapidamente, posto que é percebida como potencialmente perigosa, podendo "partir o coração" (sparge inimă). Todavia, é igualmente liberadora e catártica. "Faz bem" (gata), dizem em seguida, acrescentando que a "dor" (dor) se foi, que algo "saiu" (s-a dus).

Os prantos de supărare não duram mais do que uma ou duas melodias de "aflição" (de jale). Param sistematicamente quando tocam algumas melodias de joc ("de dança”), rápidas e em ritmo binário, que eventualmente marcam a passagem à dança. A colocação do corpo em jogo oferece, assim, uma possível via de escape aos pensamentos que "sobem à cabeça" (vine în cap, vine în minte) e a essa dor que "dói no coração". De fato, durante os momentos de supărare, o músico encontra-se inteiramente voltado para sua vida pessoal, suas lembranças, sua própria esfera de relações afetivas. Um conjunto de seres amados chega à mente, sempre na forma de figuras dolorosas: o falecido pai, uma criança doente, uma filha solitária que mora longe, um irmão na cadeia. É a música que convoca esse conjunto de seres amados, principalmente pertencentes ao círculo familiar: o músico chora ao tocar melodias "da" sua mãe, "do" seu pai" ou "do" seu irmão, ou seja, as melodias que essas pessoas gostavam de cantar ou dançar. A música contribui então para abrir uma região afetiva que não é nem pessoal, nem de outrem, mas que oscila em uma rede mais ampla de afetos. O sujeito encontra-se preso entre sua própria dor e a dos seus próximos, entre aflição e dó. É o que parece sugerir um músico ao afirmar, chorando com uma doină (canção lenta em ritmo descompassado): "É minha família que chora, não eu...".

Portanto, a relação entre música e emoções é muito diferente quando os músicos tocam entre si e para si. Não se trata mais de entender os sentimentos dos clientes para disso obter alguma vantagem, mas antes de construir um sentimento exacerbado de união entre os membros da comunidade, uma condição necessária para que a supărare se possa expressar. Não raramente pode-se ouvir os ciganos usarem em seu meio a expressão "meu irmão" ([t]mîro phral), aqui designando uma proximidade afetiva, um desejo de superar os conflitos, de se alcançar uma relação de igual para igual. Essa proximidade é igualmente física, 


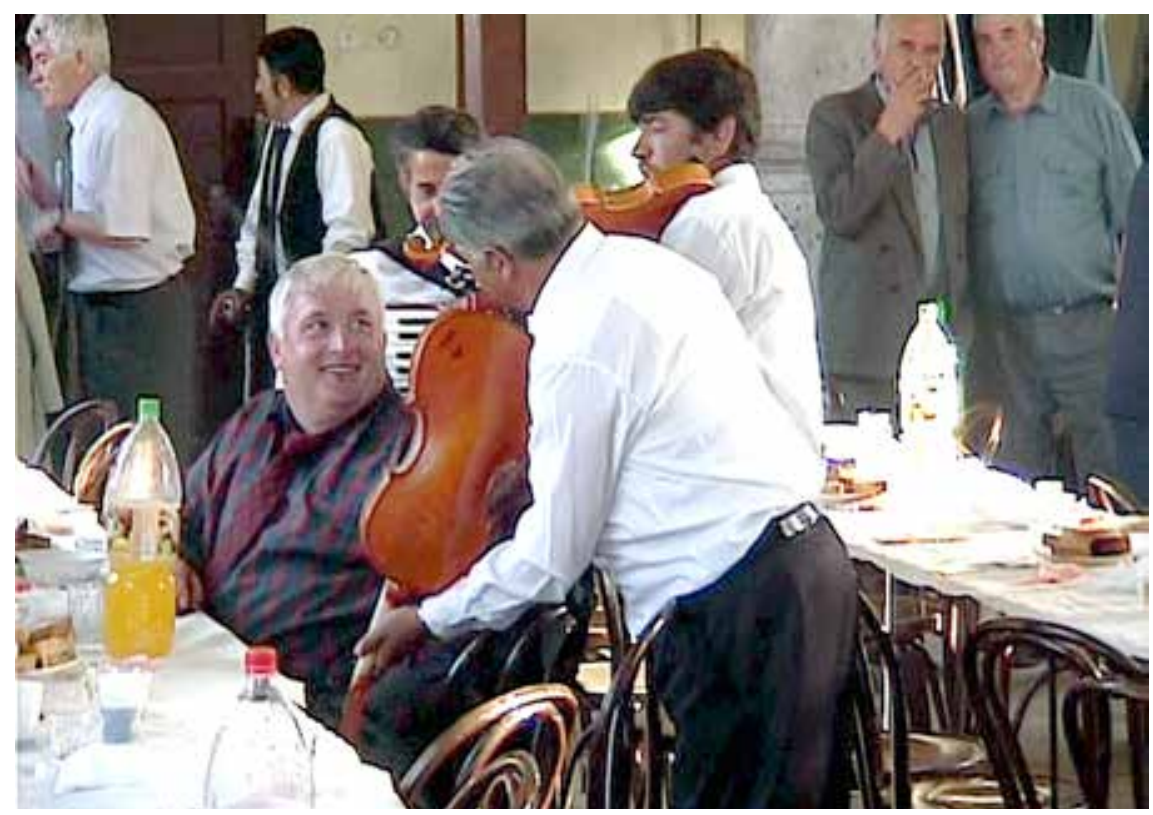

Figura 2

Csángáló e Sanyi tocam a melodia "pessoal" de Sándor durante um banquete húngaro em Ceuaș, 2004

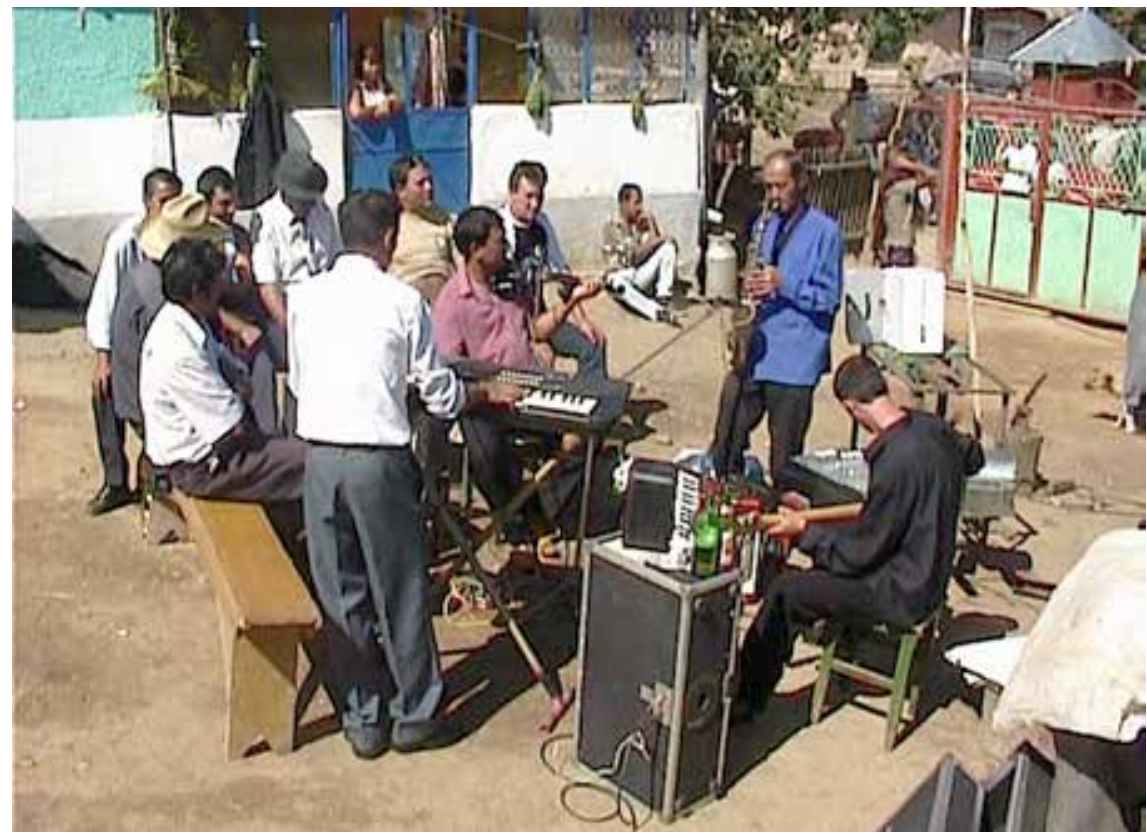

Figura 3

Festa entre músicos depois do "serviço", no bairro cigano de Ceauș, 2004 
incluindo não raramente abraços e beijos. Além da mera prática da nostalgia, do culto aos defuntos ou do ritual de igualdade entre ciganos, os prantos de supărare explicam-se, no meu entender, por uma coexistência destas duas condições existenciais: viver relações de afeto com seres ausentes (o falecido pai, a filha que vive longe, o filho na cadeia) e, simultaneamente, relações exacerbadas de proximidade com seus "irmãos" (os outros músicos que participam da festa). Desse modo, a supărare aparenta-se a uma condição de dilaceramento psicológico, devida a uma tensão entre o sentimento de união - hic et nunc - e a repentina tomada de consciência da separação de seres amados e da impotência diante de seu sofrimento (Bonini Baraldi, no prelo).

\section{Os funerais}

Em Ceauș, quando morre um cigano, o ritmo da vida cotidiana interrompe-se abruptamente. Logo se organiza o velório na casa do falecido, com duração de duas noites, e o enterro no cemitério no terceiro dia. Com exceção de alguns gadjé (os não ciganos), solicitados exclusivamente devido a sua função institucional (pastor, médico etc.), cada cigano deve escolher como se situar em relação à família do defunto, baseando-se nas relações familiares, nas afinidades e nos conflitos existentes. Essa posição determina o modo de participação de cada um e, notadamente, o que deve fazer - mas, sobretudo, o que não deve fazer - ao longo das cerimônias.

Com efeito, a morte reatualiza não apenas a clivagem entre defuntos e vivos, mas igualmente redefine as relações sociais entre os próprios vivos, segundo uma nítida, porém frágil, oposição entre "próximos" (neamuri) e "distantes" (străini, literalmente "estrangeiros") do falecido. Neamuri e străini não constituem categorias fixas, determinadas por relações precisas e imutáveis de parentesco. Em um povoado tão pequeno, a rede de parentesco é tão densa e imbricada, que algumas pessoas têm que escolher se, nessa situação específica, estarão junto aos neamuri ou aos străini. Assim sendo, cada falecimento torna-se uma oportunidade de redefinição ou confirmação da própria posição em relação aos outros, podendo cada cerimônia ter o efeito tanto de resolver quanto de exacerbar um conflito preexistente ou de redefinir uma relação de aliança ou amizade. Durante as cerimônias, essa margem de indeterminação gera tensão, assim como certa curiosidade, em que cada um avalia a adequação, ou não, do modo de participação dos demais.

As mulheres dos neamuri são as únicas que se aproximam do caixão para manifestar publicamente sua dor, proferindo lamentações ([t]rovarel din ando bari mui, literalmente "chorar de boca aberta"). Esse modo de expressão, caso fosse usado pelos străini, seria considerado inapropriado e poderia ser percebido como um sinal de proximidade afetiva sem razão de ser, quiçá ofensiva. Ao contrário, os prantos dos străini são mais íntimos e expressos apenas pelas lágrimas, sem palavras ([t]rovav an mande, literalmente "choro dentro de 
mim, intimamente"). Portanto, todo o dinamismo social associado à morte estrutura-se na interação entre duas atitudes emocionais. Enquanto os neamuri têm o dever de expressar publicamente a dor provocada pela morte, por sua vez, os străini são chamados a percebê-la e a participar. Para os próximos do defunto, um bom velório deve engajar os "distantes" no plano do afeto e provocar-lhes a milă ("dó, compaixão"), para que assim possam chorar um morto que não é o seu. A unidade do grupo, colocada em risco por um falecimento, regenera-se pela experiência vivida do sentimento que, muito mais do que qualquer outro, há de se encontrar na base desta unidade: a milă .

A análise do rito funerário permitiu esclarecer os dispositivos e as técnicas em ação na criação das relações de milă entre as pessoas presentes (Bonini Baraldi, 2008a, 20Iob). Trata-se, notadamente, de "ações sonoras": lamentos das mulheres e música instrumental a cargo dos homens. A voz das carpideiras provoca um nível mais imediato e direto de empatia: os soluços e as características do timbre de voz aproximam o lamento das sonoridades do pranto comum, sonoridades essas que estão entre os mais poderosos vetores de contágio emocional, mesmo além de qualquer fronteira cultural (Urban, I988; Meyer, Palmer \& Mazo, I998). Por outro lado, as estratégias enunciativas das lamentações suscitam a compaixão das pessoas presentes de modo mais elaborado, haja vista que exigem o conhecimento dos laços locais de parentesco. Com efeito, pronunciar um lamento constitui um meio para construir uma rede de parentescos à qual todos os neamuri são convocados, estejam eles mortos ou vivos. Não se trata de uma mera enunciação genealógica, mas de uma construção complexa de relações, obtida por constante transformação das tomadas de palavra, dos destinatários e dos locutores, em enunciados que inter-relacionam indivíduos de forma múltipla. ${ }^{9}$ Esses enunciados de tipo relacional têm como efeito sugerir outros destinatários à milă das pessoas presentes no cômodo. Estas últimas são levadas, por assim dizer, a sentir compaixão não só pela carpideira que mostra sua dor, como também pelos neamuri incluídos no discurso e que acabaram de perder um dos seus.

A música parece agir, ela também, como um poderoso meio de estabelecimento e de propagação das relações de milă. Os músicos ciganos, vindos espontaneamente ao velório, mesmo não estando próximos do falecido, tocam ao lado do caixão sequências instrumentais compostas por melodias de jale (“de afliçaõ”) e de joc (“de dança”). Esse repertório não é específico aos funerais, podendo ser ouvido em outras ocasiões, notadamente durante os casamentos (Bonini Baraldi, 2009). Para entender como a música ajuda a chorar, não nos podemos deter apenas no esquema mecanicista "música de jale = sentimento de dor" e "música de joc = alívio do sentimento de dor". Ao contrário, todos concordam em dizer que, durante os velórios, o choro se deve ao fato de os músicos tocarem a melodia "do" morto ou a de outros falecidos. Sejam elas de jale ou de joc, as melodias encontram-se investidas de imagens do falecido, de 
seus hábitos cotidianos, das relações afetivas por ele estabelecidas com seus próximos. Durante duas noites, a música permite revisitar sua vida, fazê-lo reviver e reatualizar os sentimentos associados às lembranças. ${ }^{\text {Io }}$ Essas "imagens sonoras" ajudam os neamuri a encontrar as palavras dos lamentos, e permitem aos străini dar um destino, um referente a sua jale ("aflição"), para que possa ser vivida no modo intersubjetivo da milă (“dó, compaixão").

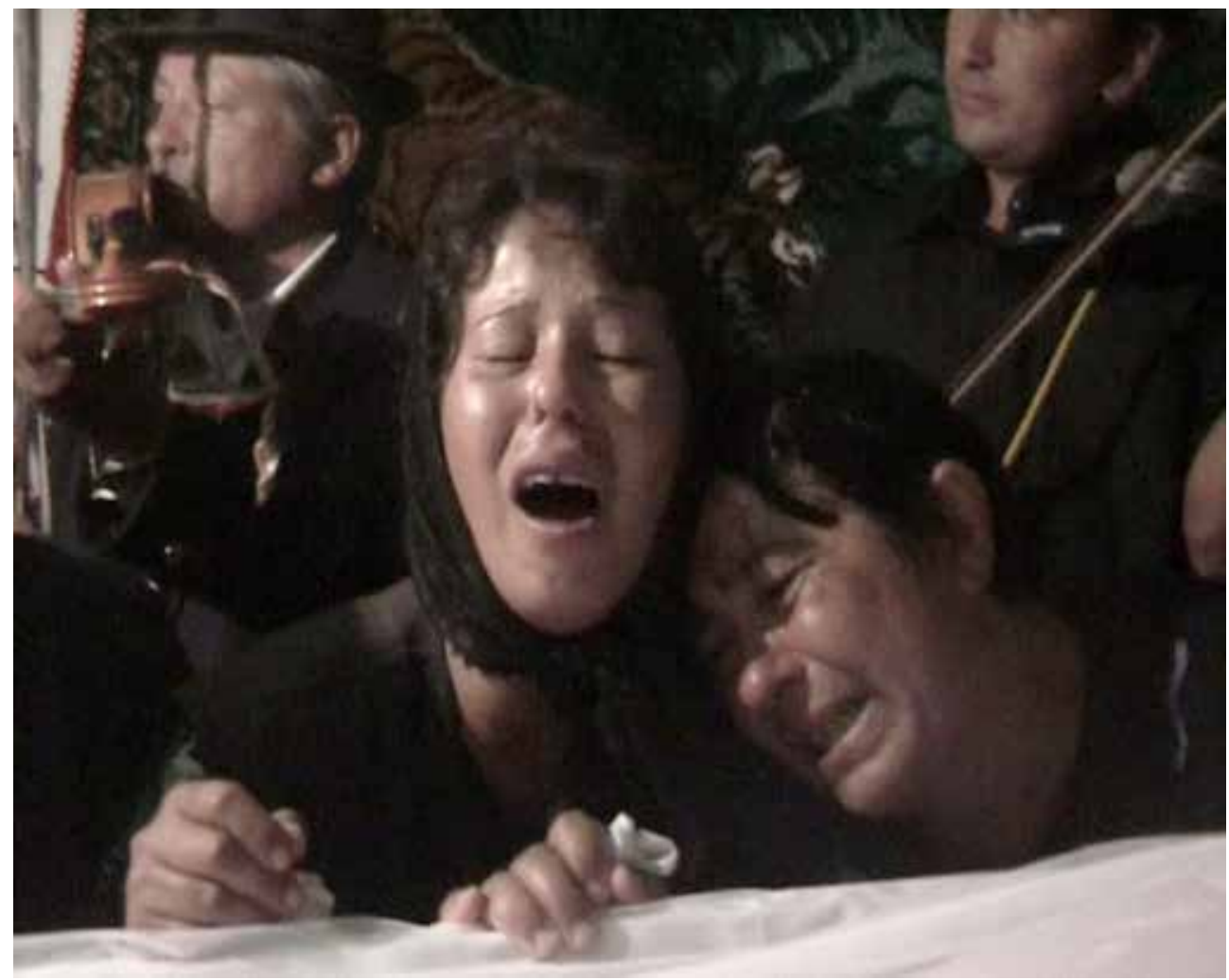

Figura 4

Velório de Áricska. No primeiro plano, as filhas Moni

e Rozi, atrás, o filho Csángáló e o neto Tocila, 2004 


\section{COMPARAÇÃO DOS TRÊS CONTEXTOS DE "PRANTOS MUSICAIS": AS DIFERENÇAS}

A comparação dessas três situações de "prantos musicais" descritas permite identificar algumas diferenças entre o serviço profissional (ao qual nos referimos adiante com a letra $\mathrm{P}$ ), as festas no bairro cigano (C) e os funerais (F). Essas diferenças advêm do tipo de contexto, das interações entre participantes, da organização do repertório musical e da maneira pelas quais se expressam as emoções, e podem ser resumidas em I 2 pontos.

I. O grau de previsibilidade e de pré-organização da performance musical. Os contratos profissionais (P) são firmados com bastante antecedência, ao passo que a música no bairro cigano $(C)$ se toca em contexto mais imprevisível e espontâneo. Os funerais (F) encontrar-se-iam a meio-termo: por mais que a morte seja inesperada, as cerimônias, por sua vez, são organizadas.

2. O estatuto do músico e a dimensão econômica. O estatuto dos músicos varia do profissionalismo (P) ao não profissionalismo (C), passando pelo semiprofissionalismo (F). De fato, eles sempre recebem remuneração quando tocam para clientes, mas nunca quando tocam entre "irmãos" no bairro cigano. No que tange aos funerais, eles podem, ou não, ser remunerados em função da relação de parentesco com a família do defunto. O custo do evento e o lucro do músico variam de acordo com o tipo de performance: alto (P), nenhum (C), variável $(\mathrm{F})$.

3. O público. Por ocasião dos casamentos, numerosos são os clientes (>IOO), de modo global externos à comunidade dos músicos; no bairro cigano, participam das festas apenas os amigos, os "irmãos" e a família (<20); nos funerais, toda a comunidade cigana está envolvida (entre 20 e Ioo pessoas).

4. A relação de poder entre músicos e público. Muito amiúde, as relações de poder são bastante sutis, sendo todavia possível distinguir as três performances em função de quem "manda" (quem tem o direito de dizer ao outro o que deve fazer). O músico está atado às exigências dos clientes (P); é "dono do pedaço" e faz o que bem entende (C); encontra-se em uma posição mais híbrida e ambígua (F).

5. A postura e o domínio de si, o álcool. Quando trabalha (P), o músico está sóbrio, elegante, adotando postura distanciada, ao passo que seus clientes se deixam levar pela festa e pelos excessos; por outro lado, quando toca no seu bairro (C), ele está no limite de suas forças e muitas vezes embriagado. Nos funerais (F), isso pode variar: geralmente, cada um está liberado para beber o quanto quiser, mas os músicos mais respeitados fazem questão de evitar os excessos.

6. A relação entre os músicos. Pode ser hierárquica, a banda sendo encabeçada por um chefe bem identificado (P); amigável, solidária e baseada em uma relação de fraternidade (C); ou ainda ambígua e de sutil competição (F). Com efeito, nos funerais, as relações de poder estabelecem-se de acordo com 
os músicos presentes. Eles podem tocar juntos ou formar grupos distintos, entrando às vezes em concorrência.

7. A escolha do repertório. A liberdade de ação quanto à música varia de um extremo a outro: dependendo dos gostos dos clientes (P), com total liberdade de escolha (C). O contexto ritual (F) impõe limitações (tocar as melodias "pessoais" do defunto), mas o músico conserva certa margem de liberdade quanto à escolha das melodias.

8. A escolha dos momentos para tocar. A temporalidade da performance segue a mesma lógica: as fases da festa e os desejos dos clientes determinam o ritmo da atividade musical (P); o músico tem liberdade de tocar ou de deixar o instrumento quando quiser (C); os funerais impõem certas obrigações à atividade musical, mas cada músico pode escolher seu momento de tocar $(\mathrm{F})$.

9. O destinatário da música. A disposição dos músicos no espaço permite localizar o principal destinatário de sua ação: eles estão inteiramente voltados para os clientes, até inclinam-se em direção a seus ouvidos (P); formam um círculo entre eles e tocam para si mesmos, sem se preocupar com as pessoas presentes (C); misturam-se à assembleia reunida em torno do caixão (F).

Io. O principal protagonista da emoção. Nas três situações descritas, aqueles que se deixam levar pelo choro são, respectivamente, os clientes (P), os músicos (C) ou todas as pessoas presentes (F). O rito funerário oferece a todos um "acesso" à emoção, ao passo que em ambos os outros casos, a emoção está, por assim dizer, "reservada" (respectivamente aos clientes e aos músicos). Nos funerais, ainda que a dimensão emocional seja mais coletiva e compartilhada, ela não deixa de ser mais heterogênea e ambígua (oposição entre prantos "de boca aberta" dos neamuri e prantos "íntimos" dos străini).

I I. A ligação entre emoção e ação musical. Nos três casos, existe uma relação distinta entre a pessoa que chora e aquela que toca. O cliente está "submetido" (emocionalmente) à ação do músico (P); com o seu tocar, o músico é ator de sua própria emoção (C); o músico contribui para a propagação e o compartilhamento da emoção, eventualmente dela participando (F).

I 2. O tipo de experiência vivida. Nas pequenas festas no bairro cigano (C), é a supărare (raiva-aflição) que está por trás das lágrimas dos músicos, ao passo que o papel central dos funerais é desempenhado pela milă (dó, compaixão) (F). Para dar conta da relação especial entre cliente, músico e emoções ao final das festas de casamento (P), propus o conceito de "ressonância". 


\section{MÚSICA}

\section{A EMOÇÃO vista pelo músico}

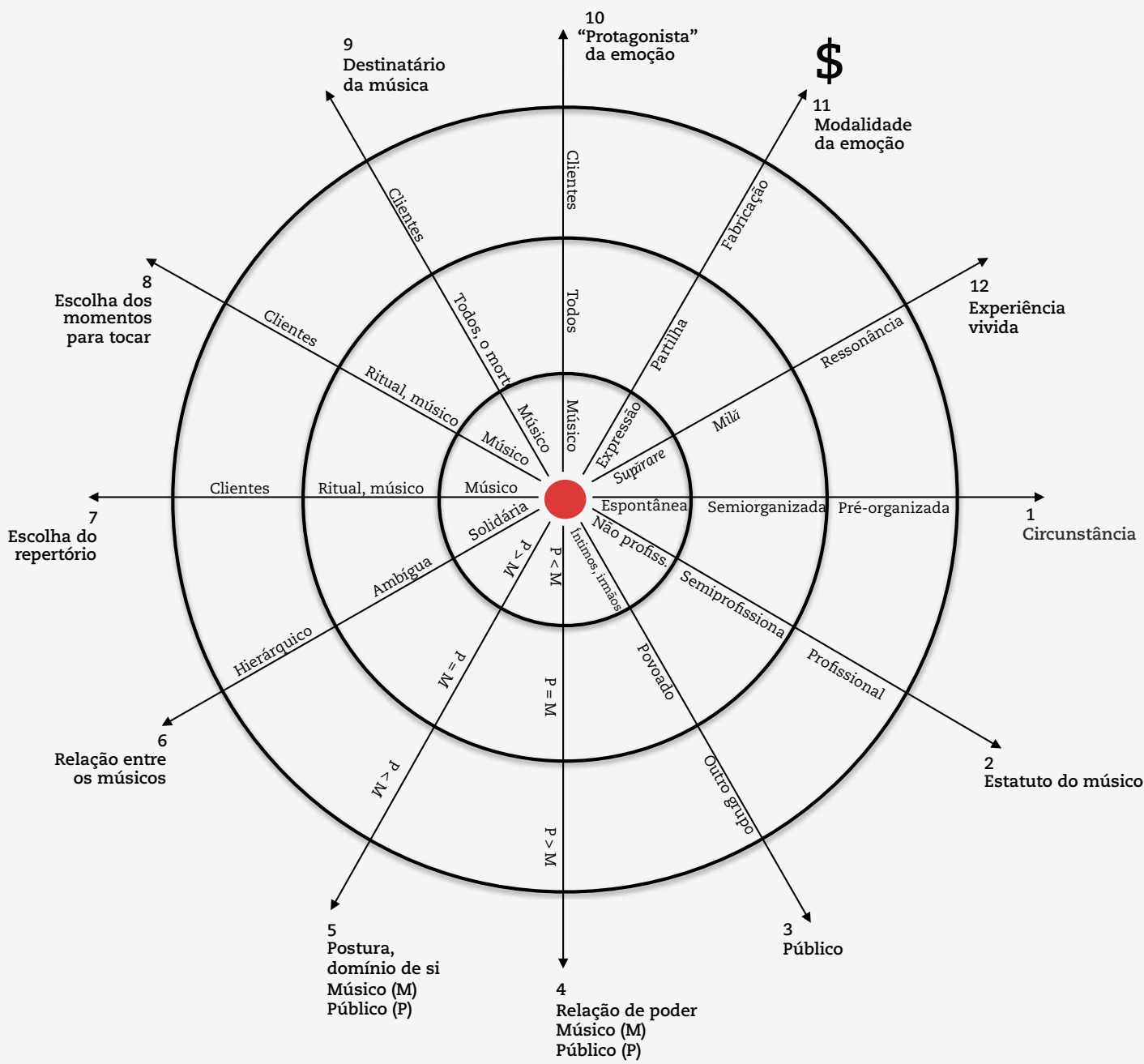


O esquema da Figura 5 ilustra todos esses fatores. A forma concêntrica desse modelo visa expressar a seguinte ideia: as três modalidades de performance organizam-se de acordo com a oposição entre regime "interno" e regime "externo" da emoção (do ponto de vista do músico). O primeiro, simbolizado pelo coração, é regido pela expressão de sentimentos pessoais no círculo das relações de fraternidade, enquanto o segundo, simbolizado pelo cifrão, é determinado por uma prática voltada para o exterior, a saber, a "venda" da emoção a clientes, com base em relações de poder e dinheiro. O rito funerário, caracterizado por certa ambiguidade quanto à vivência e à expressão das emoções, não cabe facilmente em tão nítidas oposições. Vários fatores, porém, situam-se exatamente no meio desse eixo que opõe o serviço profissional às festas no bairro cigano, permitindo assim o posicionamento do rito funerário no círculo intermediário.

É importante observar que a relação entre emoção e música dificilmente se encaixaria em unidades-blocos do tipo "contexto de performance", tais como os três esboçados na Figura 5. Em festas de I 2 horas, quando não de um dia inteiro, as emoções vividas e expressas por uns e outros evoluem ao longo de um continuum temporal, tanto quanto evoluem as relações entre os participantes. O caráter sempre dinâmico da emoção musical, porém, implicaria a renúncia de qualquer ambição de generalização e modelização? Deveria submeter-se seu estudo à análise de cada performance específica? Seria o destino de qualquer pesquisa sobre esse tema encarar um mistério, aquele da imprevisibilidade das vivências subjetivas? Se optarmos por uma resposta afirmativa a essas questões, apenas parecerá vã a tentativa de "encaixar" a emoção musical em um modelo como aquele da Figura 5.

Penso, ao contrário, que esses fatores de imprevisibilidade não são fortes o suficiente para abalar os elementos de regularidade que emergem da etnografia dos "prantos musicais". A observação de várias situações do mesmo tipo permitiu determinar de modo bastante confiável as ligações existentes entre o contexto de performance, o tipo de interação entre os participantes, a ação sobre a música, bem como os modos de vivência e de expressão das emoções. O modelo apresentado na Figura 5 ilustra essas ligações, trazendo à tona algumas tendências e orientações, e não regras absolutas. Podemos tomar como base essa modelização para propor as duas reflexões a seguir.

Em primeiro lugar, os I 2 fatores que emergiram da comparação das performances variam juntos, pelo menos até certo ponto. Em outros termos, estão correlacionadas as variáveis relativas ao contexto (I-3) às interações entre protagonistas (4-6), ao tipo de ação sobre a música (7-9) e à emoção (IoI 2). Todavia, seria muito difícil quantificar essa interdependência e determinar com precisão qual fator teria mais "peso" em detrimento dos demais. Estaria o tipo e o tamanho do público impondo diferentes posturas e relações de poder? Ou seria o álcool, sempre abordado nas conversas com os músicos, o respon- 
sável? Sem dúvida, a variável "estatuto do músico e dimensão econômica" (2) faz a performance entrar em um dos três círculos do modelo, visto que a ética do serviço, bem afirmada junto aos músicos profissionais há várias gerações, está diretamente associada a um conjunto altamente normativo de posturas e maneiras de interagir, de gerenciar a música e de provocar a emoção. Ainda mais que a oposição comunitária (ciganos versus não ciganos) é o fato de existir uma troca (dinheiro contra satisfação das expectativas) que definiria os diversos espaços sociais, propósitos e modelos de comunicação emocional.

A segunda implicação é a seguinte: se esses fatores estão correlatos, isso significaria que existem diferentes "modos" ou "modalidades" de emoção musical, os quais poderemos denominar respectivamente "fabricação da emoção" (P), "expressão da emoção" (C) e "compartilhamento da emoção" (F). A ligação entre música e emoção, portanto, não é aleatória, tampouco imprevisível, mas segue regras que dependem do contexto de performance. Em si, não há qualquer motivo para espanto: todos convirão que, em nossa sociedade, não se expressam as emoções da mesma maneira em qualquer situação. Isso, porém, tampouco significa que essas regras sejam iguais em outro contexto cultural. A meu ver, um dos objetivos das pesquisas sobre a emoção musical em etnomusicologia, consiste justamente em fazer emergirem essas correlações recíprocas entre fatores relativos à performance, à música e à emoção. Portanto, o modelo concêntrico da Figura 5, ilustrando as diversas maneiras pelas quais os ciganos de Ceuaș ligam a emoção às interações sociais e à prática da música, constitui uma síntese dessa abordagem.

\section{COMPARAÇÃO DAS TRÊS SITUAÇÕES DE "PRANTOS MUSICAIS": OS INVARIANTES}

Uma segunda maneira de extrapolar dados sobre a emoção a partir do contexto etnográfico aqui estudado, no intuito de compará-los com os referentes a práticas musicais de outras regiões do mundo, consiste em determinar os invariantes das três situações de prantos musicais, em vez de buscar as suas diferenças. Caso existam tais invariantes, há que os considerar "pontos focais" ou, por assim dizer, "estruturas profundas" da relação entre música e emoção, no sentido em que não seriam afetados pelo contexto ou pelo tipo de performance. A comparação das três situações de prantos musicais descritas permite trazer à tona três desses invariantes: I) um repertório (as melodias lentas de jale) explicitamente associado ao sentimento de "aflição" (jale); 2) o processo de associação entre pessoas específicas e estruturas musicais (as melodias "pessoais"); e 3) uma qualidade do sujeito que os ciganos ligam aos prantos: ser milos ("empático").

I. As melodias de jale. O fato do termo "aflição" (jale) ser usado para nomear parte do repertório musical indica a existência de uma estética da música feita para chorar, bem como de um discurso explícito sobre o tipo de música 
que se pretende associar a certas emoções. De fato, as melodias de jale estão presentes em todas as situações descritas. Quais seriam, portanto, as propriedades musicais dessas melodias? Em minha análise, interessei-me menos pela estrutura musical global (por exemplo, as progressões harmônicas tonais, igualmente encontradas em outros gêneros musicais dessa região) do que por um conjunto de parâmetros habitualmente menos estudados, ligados à interpretação. II Trata-se de sutil dessincronização entre melodia e acompanhamento (Bonini Baraldi, Bigand \& Pozzo, 20I5), assim como de ornamentação exacerbada da linha melódica, à qual os músicos se referem com o conceito de "doçura" (dulceață, ver Bonini Baraldi, 20I5).12 Esse conceito ocupa lugar central no discurso local: se a música tem o poder de fazer escorrer lágrimas, é porque o músico sabe tocar "com doçura" (cu dulceață); por outro lado, aquele que não conhece a doçura "faz rir" (a face să râdā). Ora, a expressão "tocar com doçura" (a cânta cu dulceață) não apenas significa decorar, ornamentar, mas igualmente "dar vida" (baga viața) a uma melodia. Ao imprimir um movimento perpétuo às notas (trilos, vibrato, mordentes, glissando etc.), o músico que tem doçura "no coração, na cabeça e nos dedos" sabe animar uma matéria sonora que, de início, não passa de algo inerte. De acordo com os ciganos, seria justamente essa qualidade de "vivente musical" que outorga poder emocional às melodias de jale.

2. As melodias pessoais. Em Ceuaș, outros gêneros musicais podem acompanhar os prantos e até mesmo melodias de dança em ritmo binário e tempos rápidos (de joc). Isso indica que a forma musical tem certa ligação com as emoções, que delas pode constituir uma possível fonte, mas que não é a única a agir e talvez sequer constitua o fator mais importante (Bonini Baraldi, 2009). Nas três situações descritas, a análise confirmou que a música veicula a emoção não tanto por suas propriedades formais, mas pela relação que sustenta com determinadas pessoas. Como se formam essas associações? Alguns reconhecem na letra de uma canção sua própria história, outros associam uma melodia a um dado momento de sua infância ou juventude ("Ficou na minha cabeça quando era criança"); há ainda os que simplesmente explicam sua relação com uma melodia dizendo: "É assim" (așa este). Remetem desse jeito a uma afinidade pessoa-melodia ancorada no inconsciente, irredutível a causas precisas e comparáveis a essas afinidades particularmente fortes que podem existir entre duas pessoas. Ainda que os "donos" das melodias não sejam unanimemente reconhecidos, todos concordam em dizer que os músicos conhecem melhor que qualquer outro as relações entre melodias e pessoas, como se desempenhassem um papel de "arquivo" da memória local. E se alguns idosos veem com maus olhos a música na moda junto aos mais novos, é porque ela seria capaz de fazer esquecer não tanto a velha música local, mas principalmente as pessoas a ela associadas.

3. O sujeito empático. Além das propriedades das melodias de jale e da "personificação" das melodias, seria preciso ter disposições específicas para 
poder chorar - ou fazer os demais chorarem - com a música? Existiria um tipo determinado de sensibilidade, uma "maneira de ser" que possa dar conta das três circunstâncias de emoção musical acima descritas? A análise sugere que "ser milos" constitui a qualidade central - não mais da música, mas do sujeito encontrada no conjunto das situações descritas. O sujeito milos é, do ponto de vista literal, aquele que tem milă, que é sensível e disposto à compaixão e à generosidade. É aquele que chora quando toca ou escuta as melodias dos seus próximos, ou ainda dos defuntos e dos distantes do povoado. Também é aquele que vai aos funerais dos outros, na expectativa explícita de chorar um morto que não é "seu". Todavia, pode-se dar um sentido mais amplo a esse termo: também é milos aquele que sabe como agir para despertar a milă do seu interlocutor, aquele que baseia as suas ações na compreensão dos sentimentos do outro, como é o caso do músico que busca conscientemente atingir o ponto sensível da "alma" (suflet) do cliente, no intuito de obter uma gorjeta. Aí reside o sentido mais geral da expressão "ser milos": agir sobre o mundo a partir da compreensão das percepções alheias. Os ciganos de Ceuaș percebem tal qualidade do sujeito como uma característica proeminente de sua identidade. "Somos", dizem eles, "mais miloși que os gaje". O sentimento de milă contribui, então, para reforçar a certeza de constituir um grupo unitário, mais precisamente uma "minoria emocional” (Bonini Baraldi, 2008b), contrastando com o modo dominante de organização dos afetos na sociedade gadji (não cigana).

\section{RUMO A UMA ABORDAGEM COMPARATIVA DA EMOÇÃO MUSICAL}

Um dos principais problemas levantados neste artigo reside em saber como extrapolar, a partir da análise etnográfica, informações que permitam comparar a emoção musical entre diversas sociedades. Tal comparação é necessária se quisermos elaborar teorias mais gerais sobre a emoção musical, no intuito de superar o quadro do repertório clássico ocidental. Porém, o que comparar exatamente? Em outras palavras, como desenvolver uma abordagem antropológica da emoção musical?

A análise das semelhanças e das diferenças entre as três situações de prantos musicais junto aos ciganos da Transilvânia permitiu trazer à tona quatros possíveis "candidatos" para uma comparação transcultural: I) os "modos" de emoção musical; 2) as melodias explicitamente associadas ao sentimento de tristeza-aflição (jale); 3) os processos de associação entre melodias e pessoas; e 4) a disposição do sujeito a ser "empático" (milos). Por que seriam esses fatores, e não outros, os melhores "candidatos" para uma comparação transcultural? O primeiro descreve, junto aos ciganos, "regras" básicas, normas, habitus da emoção musical (Becker, 200I), facilmente comparáveis aos de outras performances observadas em outras partes do mundo. A título de exemplo, se soubermos que, em dois contextos culturais diferentes, o músico está submetido à mesma prescrição de não expressar nem sentir emoções, devendo antes provocá-las junto 
a seus ouvintes, será possível comparar as estratégias usadas por ele em ambos casos. Se essas estratégias forem as mesmas (por exemplo, buscar a ativação das lembranças pessoais dos ouvintes para emocioná-los), isso significaria que existem processos da emoção musical (cognitivos, corporais e/ou sociais) recorrentes, quiçá universais. Os outros três fatores contêm informações sobre a emoção musical independentes do contexto da performance, o que nos autoriza a perguntar até que ponto também poderiam ser extrapoladas do seu contexto cultural. Não se trata aqui de desenvolver uma análise comparativa pormenorizada, mas antes de abrir caminhos de pesquisa a partir desses quatro pontos.

\section{Os "modos" da emoção musical}

O paradigma dominante das pesquisas sobre a emoção musical fundamenta-se na ideia segundo a qual os atores da performance estariam ligados entre si por uma cadeia de comunicação destinada a transmitir uma "mensagem" emocional (Meyer, I956; Sloboda \& Juslin, 2010). No caso da música clássica, essa mensagem é "codificada" pelo compositor, "transmitida" por intermédio de um intérprete, e "decodificada" pelo ouvinte, que pode eventualmente experimentar emoção. É possível encontrar esse modelo de performance em outros contextos culturais, como, por exemplo, na música clássica indiana (Benamou, 20Io), em que as "regras" que regem a relação entre música e emoção são globalmente as mesmas: o músico-compositor sente e comunica estados emocionais (rasa) ao ouvinte, escolhendo estruturas musicais (raga) adequadas a cada tipo de emoção. Ora, esse modelo de "comunicação da emoção" (Kendall \& Carterette, I990), em que pese sua ambição universal, não se pode aplicar a qualquer performance musical: os modos da emoção musical variam não somente de uma sociedade a outra (Becker, 200I), mas igualmente no seio de uma microssociedade. É o que mostra a análise das três situações de prantos musicais observadas junto aos ciganos da Transilvânia, que chamei de "fabricação da emoção" (serviço profissional), "expressão da emoção" (festas no bairro cigano) e "compartilhamento da emoção" (funerais).

Em uma perspectiva comparativa, podemos nos perguntar se existem, em outras sociedades, performances em que a relação entre emoção e música se aproximaria dessas três modalidades. Por exemplo, no mundo árabe, os músicos profissionais vivem momentos de grande intensidade emocional quando tocam em pequenos grupos, de maneira espontânea, após terem cumprido seu compromisso com os bares ou clubes que os contrataram (Racy, 2003). O tipo de emoção em jogo e o tipo de performance muito se parecem com as pequenas e espontâneas festas ciganas da Transilvânia. As mesmas estratégias usadas para comover os clientes durante o "serviço" profissional estão presentes junto aos músicos moldavos (Stoichiță, 2008) e aos roms profissionais do Kosovo (Pettan, 2002). Encontra-se também a preocupação em satisfazer os gostos dos clientes e em comovê-los junto aos músicos do Iêmen (Lambert, 
I997) e, sem dúvida, de alhures. Por outro lado, o fato de não mostrar as próprias emoções em contexto profissional, atitude característica dos músicos ciganos do Leste europeu (roms), é muito diferente da postura teatralizada e espetacular dos ciganos flamencos, baseada na expressão exacerbada das emoções, ao mesmo tempo em que se mantém certa distância em relação aos próprios sentimentos (Pasqualino, I998).

Comparações desse tipo ajudariam a estabelecer uma tipologia mais geral das relações entre música, emoção e contexto de performance. Isso permitiria "extrair" a questão da emoção musical do quadro de performance da música clássica ocidental e propor uma taxinomia precisa para se referir a diferentes situações-tipo ("comunicação", "fabricação", "expressão", "compartilhamento" etc.), assim como modelos de funcionamento para cada "modo". Tal programa de pesquisa aproximar-se-ia, do ponto de vista metodológico, do que Rouget (I980) realizou para o estudo do transe. ${ }^{\text {I3 }}$

\section{O "vivente musical"}

A música está profundamente ligada à cultura (Merriam, I964), tornando bastante improvável encontrar, em contextos sociais diferentes, as mesmas associações entre formas musicais e tipos de experiências emocionais (basta pensar no velho estereótipo ocidental que associa a tristeza ao modo menor e a alegria ao modo maior). Correspondências, entretanto, podem ser procuradas em outro nível, mais ligado à interpretação do que à estrutura (harmônica, melódica ou rítmica) de um tema. Notadamente, a associação dos ornamentos à emoção - tal como fazem os ciganos dessa região - parece muito difundida mundo afora. A respeito da música instrumental da Ásia Central, During (2004: I45) observa que "é com os gemidos e os suspiros do alaúde que se deleitam os aficionados. [...] Dir-se-á daquele que não toca esses ornamentos que ele não tem dor (dard), que sua mão é seca”. Muito antes, Sachs (I943) já observava, nas músicas do Sudeste da Ásia, a necessidade dos ornamentos para que a música possa "apelar ao coração". Assim, o ditado indiano segundo o qual "uma melodia sem ornamento é como uma noite sem lua, um rio sem água, uma planta sem flores ou uma mulher sem pedras preciosas" (Meyer, I956: 205) parece valer para muitas situações, desde a música barroca no Ocidente até a música litúrgica judia chazzanuth da Europa Oriental.

Como explicar essas frequentes associações entre os ornamentos e o "poder" emocional da música? Leonard Meyer, pesquisador muito atento aos dados provenientes da etnomusicologia de sua época, constatara a existência dessa ligação entre ornamentos e emoção em diversas regiões do mundo. Isso o levou a buscar hipóteses mais gerais, no nível dos processos de percepção, de tal sorte a descobrir o porquê de os ornamentos serem tão frequentemente as sociados a efeitos emocionais. Ele conseguiu assim integrar a questão do ornamento a sua teoria da emoção musical: os trilos, grupetos e glissandos agiriam 
como elementos aptos a instilar dúvida e incerteza, obscurecendo temporariamente os motivos musicais (patterns) e contribuindo assim para a inibição das tendências, fonte psicológica de emoção. Ora, no desenvolvimento da sua teoria, Meyer não levava em consideração uma ideia que me parece fundamental e que essas mesmas fontes sugeriam: a de "vivente musical".

Os ciganos de Ceuaș dizem explicitamente que é preciso "pôr vida" na música. Tal "vida" expressa-se formalmente por meio de uma elaboração exacerbada da linha melódica (introdução de inúmeras variações, fiorituras, ornamentos, vibratos etc.), dando a impressão de movimento perpétuo. É interessante observar a existência da mesma ideia em outras sociedades: "A música dos eslavos do sul é particularmente atraente. Talvez se deva ao contraste entre a simplicidade essencial de seus elementos de base e a qualidade de vida palpitante (pulsing quality of life) que deriva da abundância dos recursos expressivos, incluída a ornamentação" (Herzog apud Meyer, I956: 2 I 2, grifos meus). Em outras tradições musicais, existiria igual tendência a se transformar um "objeto sonoro" em verdadeiro "ser sonoro", de modo a aumentar a sua eficiência emocional? Quais propriedades acústicas seriam necessárias para a música adquirir qualidades "vivas"? Estaria essa "vida" da música ligada a uma ideia de movimento, obtido por diversos meios (vibratos, trilos, glissandos etc.)? Se, por um lado, as pesquisas comparativas sobre a estética nas músicas do mundo focalizam as noções de "belo" ou de "gosto musical" (ver Cahiers d'ethnomusicologie, 28, 20I5), por outro, seria igualmente útil desenvolver uma análise comparativa do "vivente musical", um critério que poderia estar associado, de maneira fundamental, aos efeitos emocionais dos artefatos artísticos. Do ponto de vista teórico, isso permitiria compreender essa eficiência emocional não como resultado de uma operação mental (inibição das tendências, ver Meyer, I956), mas antes em termos de "animação", corporal e perceptiva, do objeto sonoro (Bonini Baraldi, 20I5). ${ }^{\text {I4 }}$

\section{As melodias "pessoais"}

Junto aos ciganos de Ceuaș, essa tendência de "animar" a música manifesta-se igualmente via associações explícitas entre melodias e pessoas específicas. $\mathrm{Na}$ música clássica ocidental quase não há relação entre formas sonoras e entidades determinadas (divindades, pessoas etc.), razão pela qual, na literatura científica, fala-se simplesmente de um efeito de memória episódico conhecido sob a expressão "Meu amor, essa é a nossa música!" (Juslin \& Västfjäll, 2008). Todavia, processos de personificação e animação da música são muito presentes no mundo: foram observadas melodias "pessoais" em outras regiões do Leste Europeu (Sárosi, I978; Stewart, I997; Bouët, Lortat-Jacob \& Rădulescu, 2002; Stoichiță, 2008), assim como em sociedades mais distantes. Junto aos Suyá da Amazônia brasileira (Seeger, 2004), as canções "pessoais" contribuem para afirmar relações de parentesco; são transmitidas dos adultos aos jovens rapazes durante cerimônias de iniciação, junto com ornamentos corporais, diferentes para cada sub- 
grupo da comunidade. ${ }^{15}$ Alhures, esses "seres" ou "agentes" sonoros são de outra natureza, como divindades (caso muito frequente nos rituais de transe, ver Rouget, I980), animais ou outras entidades, conquanto sejam percebidas como vivas.

É importante precisar que frequentemente essas associações não são usadas para lembrar-se de alguém ou de algo, mas antes para interagir com uma entidade viva. Nos ritos de possessão do Bastar (Índia) descritos por Prévôt (20 I I), convocam-se divindades na "feira dos deuses" (deu bajar) tocando suas melodias (par), no intuito de com elas estabelecer um diálogo. Nesse caso, a música não constitui um mero apelo ao espírito ou uma representação do espírito; seria antes o espírito, ele próprio, que se manifesta em sua forma sonora. Em outros casos, a música permite realizar "transmutações de intencionalidades" (Surrallès, 2003). Por exemplo, junto aos Candoshi da Amazônia peruana, estudados por Surrallès (2003), os encantamentos tiram sua eficiência do fato de permitir ao cantor identificar-se com outro ser vivo. Quando é pronunciado um encantamento para favorecer a caça, espera-se do cantor que se transforme em um membro da espécie que se almeja capturar (caça, peixe etc.). Assim, cada animal ou espécie tem o seu "canto" específico. Trata-se aqui de outra forma de animação da música, baseada na identificação do cantor com um ser vivo, mas o princípio permanece o mesmo: uma melodia ou um ritmo, associados de modo durável a um ser vivo, são tratados como se fossem, pelo menos em parte, esse próprio ser. Dessarte, os cantos adquirem estatuto ontológico particular, como se tivessem "uma existência autônoma, positiva e independente do espírito que os produz" (Surrallès, 2003: 229).

A questão dos "agentes sonoros", pertinente em inúmeras sociedades, mereceria ser integrada às teorias da emoção musical (Bonini Baraldi, no prelo). É então possível se perguntar: que tipos de interação se produziriam entre esses agentes e os humanos? Pode-se falar de "antropomorfismo musical" e invocar as teorias propostas pelos antropólogos especializados nesse domínio (entre outros, Boyer, I996)? Que operações mentais e corporais permitiriam perceber a música como um "ser intencional", com capacidade para surtir efeitos no mundo e notadamente para comover o ouvinte? (Gell, I998; Leman, 2007).

\section{Música e empatia}

Os ciganos associam os prantos musicais a uma qualidade do sujeito que chamam de milă e poderia ser traduzida por "dó", "compaixão" ou, de modo mais amplo, "empatia". O propósito de uma pesquisa comparativa seria então identificar se a noção de empatia poderia ser útil para explicar os efeitos emocionais da música.

Para dar um exemplo, Lutz (I988) analisou os significados do termo fago junto aos Ifaluk da Micronésia, a saber, um sentimento central nas relações interpessoais traduzido pelo autor por "compaixão, amor, tristeza" (com- 
passion, love, sadness). De modo quase idêntico à explicação dada pelos ciganos à milă, vê-se que os Ifaluk dizem sentir fago não só por um falecido ou uma pessoa que sofre, mas também pela música. De modo semelhante, Feld (I982) observa que junto aos Kaluli da Papua-Nova Guiné o prefixo gese designa não apenas o ato de despertar dó (notadamente no caso de uma criança que chora), mas igualmente uma forma sonora específica, ou seja, o intervalo descendente de segunda maior. Na sua etnografia dos Yap da Micronésia, Throop (20II) observa que existe forte propensão para a compaixão pelo sofrimento alheio, principalmente no âmbito das relações familiares e comunitárias. A expressão kab amiithum ngeak, significando literalmente "eis a sua dor", expressa imagens de grande preocupação, amor e compaixão pelo outro. Ora, esses sentimentos de dó e compaixão estão também no cerne de um determinado repertório musical, as canções de amor, nas quais frequentemente se encontra a expressão be liyeg amiithuun, que significa "sua dor, ou seu sofrimento, está me matando". O efeito desses cantos consiste em despertar o mesmo sentimento junto ao ouvinte e assim trazer sua empatia.

Esses exemplos sugerem que os domínios semânticos de dó, compaixão e empatia são usados para descrever o efeito emocional que acompanha a escuta de certas formas sonoras e, eventualmente, para nomear essas mesmas formas sonoras. Isso se afasta das pesquisas científicas sobre o repertório clássico (Sloboda \& Juslin, 20ıо), que se refere a alegria, serenidade, tristeza, raiva, medo, calma, surpresa, mas nunca a dó, compaixão ou empatia por (ou com) a música. Assim surgem novas perguntas: abrir-se aos outros e abrir-se à música dependeriam de uma mesma sensibilidade, de uma mesma faculdade? Seria preciso ter disposições empáticas para poder emocionar-se com a música?

O papel da empatia na experiência estética constitui hoje uma questão de grande atualidade científica. Os modelos que explicam os mecanismos de percepção e de criação artística em termos de elaboração cognitiva das formas são progressivamente substituídos por outros que destacam o papel fundamental das faculdades de simulação, de imitação e de animação empática (Gell, I998; Berthoz \& Jorland, 2004; Freedberg \& Gallese, 2007; Leman, 2007). As pesquisas conjuntas dos especialistas da arte e dos neurocientistas multiplicam-se, e observa-se ainda a emergência de uma área de estudos chamada "neuroestética"(Zeki, 2002). No tocante a todas essas pesquisas, por vezes tendentes a explicar um fato macroscópico (os efeitos das obras de arte) apenas a partir do nível microscópico (o processo dos "neurônios espelhos", considerados a base da empatia intersubjetiva), o nosso propósito consiste em desenvolver um verdadeiro paradigma antropológico, fundamentado em inúmeros exemplos oriundos das mais diversas culturas. Trata-se igualmente de comprovar se, nessa propensão humana para engajar-se em relações empáticas via um artefato e com um artefato, existiria algo específico ao domínio sonoro. 


\section{CONCLUSÃO}

A etnomusicóloga americana J. Becker (200I:I45) sugere que "a alegria (happiness) é a emoção mais frequentemente associada à escuta musical e poderia constituir um dos universais dos estudos transculturais sobre a emoção musical". De fato, além das construções culturais da alegria, essa emoção seria, em parte, o mero resultado da excitação musical (musical arousal). Em outras palavras, o homem tenderia a se sentir melhor quando se encontra "musicalmente excitado" (musically aroused and excited). Sem dúvida, essa ligação entre música e alegria ou até mesmo euforia ${ }^{16}$ caracteriza inúmeras performances musicais mundo afora, sendo a dança o comportamento mais frequentemente associado.

Se a dança, por si só, constitui hoje um domínio de estudo, proponho dedicar igual atenção e desenvolver ferramentas conceituais e metodológicas adequadas para explicar outras experiências emocionais intensas que ocorrem juntamente com a música, sobretudo os "prantos musicais". Nesse mesmo sentido, o psicólogo sueco A. Gabrielsson (20 I I) lançou recentemente um programa de pesquisa denominado SEM (Strong Experiences with Music), no intuito de explicar os fatores que poderiam despertar tais reações. Infelizmente, os dados do projeto SEM não chegam a ultrapassar o quadro da cultura ocidental, ao passo que a abordagem etnomusicológica tem muito a dizer sobre o assunto, já que os "prantos musicais" são pelo menos tão difundidos nas sociedades do mundo quanto as expressões de euforia e alegria. ${ }^{17}$

O primeiro objetivo deste artigo consistiu em analisar as relações entre música e prantos, em um contexto cultural bem delimitado: uma comunidade cigana da Transilvânia. Em um primeiro momento, minha metodologia baseou-se na descrição, na análise e na interpretação de diversas performances em que música e pranto encontram-se associados. Em um segundo tempo, comparei essas situações para trazer à tona suas diferenças e assim chegar a um modelo que sintetizasse a maneira pela qual a relação entre música e emoção muda em função do contexto de performance. Em seguida, a comparação desdobrou-se em torno dos invariantes, mais do que das diferenças. Isso permitiu destacar, junto aos ciganos de Ceuaș, as constantes da emoção musical, por mim definidas como "pontos focais" ou "estruturas profundas" da relação entre música e emoção, no sentido em que não são afetadas pelo contexto ou pelo tipo de performance. Esses quatro fatores (os modos da emoção musical, o "vivente musical", a personificação das melodias e a empatia) constituem possíveis "candidatos" para uma comparação que, no futuro, deverá permitir elaborar considerações mais gerais - e menos etnocêntricas - acerca da relação entre música e emoções humanas. 
Filippo Bonini Baraldi é engenheiro e músico, doutor em etnologia pela Universidade Paris Ouest Nanterre. Atualmente é pesquisador do Instituto de Etnomusicologia (INET-md), da Faculdade de Ciências Sociais e Humanas da Universidade Nova de Lisboa. Lecionou etnomusicologia na Universidade Paris 8 - St. Denis e na Universidade Federal da Paraíba (UFPA). Suas pesquisas exploram a ligação entre música, emoção e empatia, segundo uma abordagem interdisciplinar. Em 2013 publicou seu primeiro livro, Tsiganes, musique et empathie (premiado pela Academia Charles Cros). 


\section{NOTAS}

I Para Spinoza (I954), as emoções são "afecções do corpo, pelas quais sua potência de agir é aumentada ou diminuída, estimulada ou refreada, e, ao mesmo tempo, as ideias dessas afecções". Damasio (I995), em seus importantes trabalhos sobre as emoções, inspira-se nessa mesma definição.

2 As dificuldades metodológicas levantadas pelo estudo das emoções em suas dimensões social e cultural sem dúvida explicam esse atraso. Com efeito, foi preciso esperar os anos I980 para que os etnólogos começassem a estudar a maneira pela qual outras sociedades concebem, nomeiam e expressam as emoções (Lutz \& White, I986). Hoje, vários autores demostraram nitidamente que o estudo das emoções se articula de modo fecundo com áreas mais clássicas da antropologia (identidade, política, organização social, ritual, gênero etc. Ver, entre outros, Surrallès, 2003; Héritier \& Xanthakou, 2004; Pasqualino, 2005; Houseman, 2006; Lüddeckens, 2006; Berthomé \& Houseman, 2010).

3 Em artigo recente, Juslin \& Västfjäll (2008: 559) observam que: "apesar do aumento recente das pesquisas sobre emoções musicais (ver Juslin \& Sloboda, 200I para uma resenha extensa), a literatura apresenta um quadro confuso com perspectivas conflitantes acerca de praticamente qualquer tópico nesse campo de estudos" [tradução minha].

4 Conduzi pesquisa de campo na Transilvânia graças à bolsa de doutoramento do CNRS (Centre National de Recherche Scientifique) entre 2003 e 2006, à bolsa de pós-doutorado 'E. Fleischmann' da Sociedade de Etnologia (Nanterre, France), e ao apoio financeiro do Centre de Recherche en Ehtnomusicologie (CREM-LESC, Université Paris Ouest Nanterre, France). Este artigo foi possível graças ao Programa "Investigator FCT", (INET-md, FCSH, UNL, Portugal). O autor agradece aos pareceristas anônimos as pertinentes sugestões e os comentários recebidos e a David Yann Chaigne a tradução do original em francês.

5 O autor utiliza o termo francês "tsiganes" em detrimento de "roms" ou "rroms", muito embora estes dois últimos sejam mais usuais na linguagem oficial da Europa Oriental e notadamente no discurso político. Em português, optamos pelo termo "ciganos". [N.T.] 
6 A análise aqui apresentada baseia-se na observação, entre 2004 e 2006, de oito festas de casamento, sete festas espontâneas no bairro cigano e dez ritos funerários. Para descrição detalhada, vide Bonini Baraldi (2013). Vídeos ilustrando as performances aqui descritas estão disponíveis em: http://www.ethnomusicologie.fr/tsiganes-bonini-baraldi. Ao longo deste artigo, os termos vernaculares romenos estão destacados em itálico, e os termos em romani (a língua cigana) estão precedidos pela letra [t].

7 Todas as fotografias são de minha autoria: (c Filippo Bonini Baraldi.

8 Esse conceito está aqui entendido na sua acepção literária: "Efeito do que se repercuta no espírito, eco, estrondo", por sua vez baseada em um fenômeno físico: "Fenômeno pelo qual um sistema físico em vibração pode atingir uma amplitude muito grande, quando a vibração excitadora se aproxima de uma 'frequência natural' desse sistema" (Robert, 2007).

9 Para uma análise detalhada dos enunciados relacionais do lamento, ver a animação interativa Lamentation funèbre, disponível em: <http://www.ethnomusicologie.fr/tsiganes-bonini-baraldi $>$.

Io As melodias "pessoais" em contexto de luto emergem de modo marcante na ocasião das celebrações do Io de novembro, Dia de Finados, quando os músicos percorrem o cemitério tocando as melodias "de" cada morto.

I I Pode-se ver, nesta maneira de proceder, uma ligação com certa musicologia da emoção, focalizada mais nas microvariações expressivas do que nas macroestruturas do repertório (Gabrielsson, I995).

I 2 Para uma análise detalhada da doçura e da dessincronização entre melodia e acompanhamento, vide a animação interativa Jouer la jale, disponível em: http://www.ethnomusicologie.fr/tsiganes-bonini-baraldi. O filme Plan-séquence d'une mort criée (Bonini Baraldi, 2005) mostra como lamentações e música instrumental contribuem para criar a intensidade emocional típica dos velórios dos ciganos de Ceuaș.

I3 A comparação de diversos ritos e performances permitiu que Rouget (I980) propusesse uma taxinomia precisa para dis- 
tinguir situações em que a relação entre música e possessão segue regras diferentes: "xamanismo", "transe emocional", "transe induzido", "transe conduzido" etc.

I4 De acordo com Gell (I998), essa "animação" se encontra particularmente favorecida no caso de motivos decorativos e ornamentados, já que estimulam um movimento real do corpo, em curso no ato de percepção e, de alguma maneira, projetado sobre o próprio artefato, dando a impressão de ter na sua frente um "ser animado". Para uma discussão mais ampla, ver Bonini Baraldi (2015)

I5 Seeger (2004) aborda essa "personificação" dos cantos de maneira bastante explícita: "Every song had a 'master' or 'owner', which could be an individual or a group. Shout songs belonged to individuals and unison songs belonged to groups, althought they both had origins from the animal domain." (Seeger, 2004: 75). "The shout songs were as individualized as the spirit. Each person had his own for each ceremony, of a style more or less appropriate to his age." (Seeger, 2004: I 29).

I6 Ver Seeger (2004: I7): "When people feel euphoric, they are happy and want to sing. Singing makes them happy".

I7 Numerosos são os exemplos etnográficos de "prantos musicais", e não se limitam ao contexto dos ritos funerários (entre outros, ver Rouget, I980). Para dar um só exemplo, oriundo do contexto brasileiro, A. Seeger (2004: 75) observa que "another female constribution to the total aural effect of [Suyá] ceremonies was crying. Adult women often cried at the start of a ceremony, when they remembered and commemorated their dead relatives who used to enjoy it particularly, or when a brother left their houses after being adorned for his solo singing".

\section{REFERÊNCIAS BIBLIOGRÁFICAS}

Becker, Judith O. (2004). Deep listeners. Music, emotion and trancing. Bloomington: Indiana University Press.

Becker, Judith O. (200I). Anthropological perspectives on music and emotion. In: Juslin, Patrick N. \& Sloboda, John A. (orgs.). Music and emotion: Theory and research. Nova York: Oxford University Press, p.135-160. 
Benamou, Marc. (2010). Rasa: affect and intuition in Javanese musical aesthetics. Nova York: Oxford University Press.

Berthomé François \& Houseman, Michael. (2010). Ritual and emotions: moving relations, patterned effusions. Religion and Society: Advances in Research, I, p. 57-75.

Berthoz, Alain \& Jorland, Gérard. (2004). L'empathie. Paris: Odile Jacob.

Blacking, John. (1973). How musical is man? Washington: University of Washington Press.

Bonini Baraldi, Filippo. (no prelo). Embodied interaction with "sonic agents": an anthropological perspective. In: Lesaffre, Micheline; Maes, Pieter-Jan \& Leman, Marc (orgs.). The Routlege companion to embodied music interaction. Nova York: Routledge.

Bonini Baraldi, Filippo. (20I5). La douceur, critère d'appréciation esthétique chez les Tsiganes de Transylvanie. Cahiers d'Ethnomusicologie, 28, p. 23-4I.

Bonini Baraldi, Filippo. (2013). Tsiganes, musique et empathie. Paris: Editions de la Maison des Sciences de l'Homme. Bonini Baraldi, Filippo. (20I0a). Jouer aux noces, puis entre soi. Le cycle de l'émotion chez les musiciens tsiganes de Transylvanie. Cahiers d'Ethnomusicologie, 23, p. 85-IO2.

Bonini Baraldi, Filippo. (20Iob). “C'était toi ma pitié!" Le discours pleuré dans les veillées funéraires des Tsiganes de Transylvanie. In: Dupont, Florence; Lortat-Jacob, Bernard \& Manca, Maria (orgs.). La voix actée. Pour une nouvelle ethnopoétique. Paris: Kimé, p. 22 I-228.

Bonini Baraldi, Filippo. (2009). All the pain and joy of the world in a single melody: a transylvanian case study on musical emotion. Music Perception, 26/3, p. 257-26I.

Bonini Baraldi, Filippo. (2008a). L'expérience de la musique instrumentale dans les veillées funéraires des Tsiganes de Transylvanie. Frontières, 20/2, p. 67-70.

Bonini Baraldi, Filippo. (2008b). The Gypsies of Ceuaș, Romania: an "emotional minority"? In: Statelova, Rosemary et al. (orgs.). The human world and musical diversity: proceedings from the Fourth Meeting of the ICTM Study Group "Music and Minorities" in Varna, Bulgaria 2006. Sofia: Bulgarian Academy of Science, p. 255-26I. 
Bonini Baraldi, Filippo; Bigand, Emmanuel \& Pozzo, Tierry. (2015). Analyzing and representing Transylvanian village music by using motion capture. Empirical Musicology Review, Io/4, p. 265-29I.

Bouët, Jacques; Lortat-Jacob, Bernard \& Speranța Rădulescu. (2002). À tue-tête. Chant et violon au Pays de l'Oach. Nanterre: Société d'ethnologie.

Boyer, Pascal. (1996). What makes anthropomorphism natural: intuitive ontology and cultural representations. Journal of The Royal Anthropological Institute, 2, p. 83-97.

Budd, Michael. (1985). Music and the emotions: the philosophical theories. Londres: Routledge.

Cahiers d'Ethnomusicologie, 28. (20I5). Le goût musical.

Cler, Jérôme. (2010). Anti-Pathos. L'affect proprement musical dans une société d'ascendance nomade, en Turquie méridionale. Cahiers d'Ethnomusicologie, 23, p. Io I-I I I.

Damasio, Antonio. (I995). L'erreur de Descartes. La raison des émotions. Paris: Odile Jacob.

Demeuldre, Michel. (2004). Sentiments doux-amers dans les musiques du monde. Paris: L'Harmattan.

During, Jean. (2004). De la nostalgie et de la peine comme fondements des traditions musicales. In: Demeuldre, Michel (org.). Sentiments doux-amers dans les musiques du monde. Paris: L'Harmattan, p.I37-I47.

Egermann, Hauke et al. (20I5). Music induces universal emotion-related psychophysiological responses: comparing Canadian listeners to Congolese Pygmies. Frontiers in Psychology, 5. Disponível em: <http://journal.frontiersin. org/article/I0.3389/fpsyg.20 I 4.0I34I/pdf>. Acesso em 30 nov. 2016.

Ekman, Paul et al. (orgs.). (2003). Emotions inside out. I 30 years after Darwin's The expression of the emotions in man and animals. Nova York: Annals of the New York Academy of Sciences.

Feld, Steven. (1982). Sound and sentiment. Birds, weeping, poetics, and song in Kaluli expression. Philadelphia: University of Pennsylvania Press.

Freedberg, David \& Gallese, Vittorio. (2007). Empathy, motion and emotion. In: Herding, Klaus \& Krause-Wahl, Antje 
(orgs.). Wie sich Gefühle Ausdruck verschaffen: Emotionen in Nahsicht. Berlim: Driesen, p. I7-5I.

Fritz, Thomas et al. (2009). Universal recognition of three basic emotions in music. Current Biology, I9, p. 573-576.

Gabrielsson, Alf. (20I I). Strong experiences with music. Nova York: Oxford University Press.

Gabrielsson, Alf. (I995). Expressive intention and performance. In: Steinberg, Reinhard (org.). Music and the mind machine. Berlim: Springer-Verlag, p. 35-47.

Geertz, Clifford. (I973). The interpretation of cultures. Nova York: Basic Books.

Gell, Alfred. (1998). Art and agency. An anthropological theory. Oxford: Clarendon Press.

Heritier, Françoise \& Xanthakou, Margarita (orgs.). (2004). Corps et affects. Paris: Odile Jacob.

Herzog, George. (I95I). Introduction. In: Bartók, Béla \& Lord, Albert Bates (orgs.). Serbo-Croatian folk songs. Texts and transcriptions of seventy-five folk songs from the Milman Parry collection and a morphology of Serbo-Croatian folk melodies. Nova York: Columbia University Press.

Houseman, Michael. (2006). Relationality. In: Kreinath, Jens; Snoek, Jan \& Stausberg, Michael (orgs.). Theorizing rituals. Classical topics. Theoretical approaches. Analytical concepts. Annotated bibliography. Leiden: Brill, p. 4I3-428.

Juslin, Patrik N. \& Västfjäll, Daniel. (2008). Emotional responses to music: the need to consider underlying mechanisms. Behavioral and Brain Sciences, 3I, p. 559-575.

Juslin, Patrik N. \& Sloboda, John A. (200I). Music and emotion: Theory and research. Nova York: Oxford University Press.

Kendall, Roger A. \& Carterette, Edward C. (I990). The communication of musical expression. Music Perception, 8, p. I 29- I 64 .

Lambert, Jean. (1997). La médecine de l'âme: le chant de Sanaa dans la société yéménite. Nanterre: Société d'ethnologie.

Leavitt, John. (1996). Meaning and feeling in the anthropology of emotions. American Ethnologist 23, p. 514-539.

Leman, Marc. (2007). Embodied music cognition and mediation technology. Cambridge: The MIT Press. 
Lewis, Michael, Haviland-Jones, Jeannette M. \& Feldman Barrett, Lisa (orgs.). (2008). Handbook of emotions. Nova York: The Guilford Press.

Lortat-Jacob, Bernard. (I 994). Musiques en fête. Maroc, Sardaigne, Roumanie. Nanterre: Société d'Ethnologie.

Lüddeckens, Dorothea. (2006). Emotion. In: Kreinath, Jens; Snoek, Jan \& Stausberg, Michael (orgs.). Theorizing rituals. Classical topics. Theoretical approaches. Analytical concepts. Annotated bibliography. Leiden: Brill, p. 545-570.

Lutz, Catherine. (I988). Unnatural emotions. Everyday sentiments on a Micronesian atoll and their challenge to Western theory. Chicago: University of Chicago Press.

Lutz, Catherine \& White, Geoffrey M. (I986). The anthropology of emotions. Annual Review of Anthropology, I5, p. 405-436.

McAllester, David P. (I97I). Some thoughts on "universals" in world music. Ethnomusicology, I5/3, p. 379-380.

Merriam, Alan P. (I964). The anthropology of music. Evanston: Northwestern University Press.

Meyer, Leonard B. (1956). Emotion and meaning in music. Chicago: University of Chicago Press.

Meyer, Rosalee K.; Palmer, Caroline \& Mazo, Margarita. (I998). Affective and coherence responses to Russian laments. Music Perception, I6/I, p. I35-I50.

Molino, Jean \& Nattiez, Jean-Jacques. (2007). Typologies et universaux. In: Nattiez, Jean-Jacques (org.). Musiques. Une encyclopédie pour le XXI ${ }^{e}$ siècle. Paris: Actes Sud/Cité de la Musique, p. 337-396.

Pasqualino, Caterina. (2005). Écorchés vifs. Pour une anthropologie des affects. Systèmes de pensée en Afrique noire, I7, p. 5I-69.

Pasqualino, Caterina. (1998). Dire le chant. Les gitans flamencos d'Andalousie. Paris: Editions de la Maison des Sciences de l'Homme/CNRS.

Peretz, Isabelle \& Zatorre, Robert J. (orgs.). (2003). The cognitive neuroscience of music. Nova York: Oxford University Press. Pettan, Svanibor. (2002). Rom musicians in Kosovo: interaction and creativity. Budapeste: Institute for Musicology of the Hungarian Academy of Sciences. 
Prévôt, Nicolas. (20 I I). Corps, esprit(s), musique... possession au Bastar, Inde centrale. In: Musique, corps, âme. Paris: Cité de la musique, p. 75-87.

Racy, Ali J. (2003). Music making in the Arab world: The culture and artistry of tarab. Cambridge: Cambridge University Press. Robert, Paul. (2007). Dictionnaire de la langue française. Paris: SNL - Le Robert.

Rouget, Gilbert. (I980). La musique et la transe. Paris: Gallimard.

Sachs, Curt. (1943). The rise of music in the ancient world, East and West. Nova York: Norton.

Sárosi, Bálint. (I978) [I97I]. Gypsy music. Budapeste: Corvina Press.

Seeger, Anthony. (2004) [1987]. Why Suya sing. A musical anthropology of an Amazonian people. Urbana/Chicago: University of Illinois Press.

Sloboda, John A. \& Juslin, Patrick N. (2010). Handbook of music and emotion: theory, research, applications. Oxford: Oxford University Press.

Spinoza, Baruch. (I954) [I677]. L'éthique. Paris: Gallimard.

Stewart, Michael C. (1997). The time of the Gypsies. Oxford: Westview.

Stoichiță, Victor A. (2008). Fabricants d'émotion. Ruse et malice dans un village tsigane de Roumanie. Nanterre: Société d'Ethnologie.

Surrallès, Alexandre. (2003). Au coeur du sens. Perception, affectivité, action chez les Candoshi. Paris: CNRS/Maison des Sciences de l'Homme.

Surrallès, Alexandre. (2000). Émotion. In: Bonte, Pierre \& Izard, Michel (orgs.). Dictionnaire de l'ethnologie et de l'anthropologie. Paris: PUF, p. 785-786.

Throop, Jason, C. (20I I). Suffering, empathy, and ethical modalities of being in Yap (Waqab), Federated States of Micronesia. In: Hollan, Douglas W. \& Throop, Jason C. (orgs.). The anthropology of empathy: experiencing the lives of others in Pacific societies. Oxford: Berghahn, p. II9-I5O.

Urban, Greg. (1988). Ritual Wailing in Amerindian Brazil. American Anthropologist, 90, p. 385-400. 
Wolf, Richard K. (200I). Emotional dimensions of ritual music among the Kotas, a South Indian Tribe. Ethnomusicology, 45, p. 379-422.

Zeki, Semir. (2002). Neural concept formation and art: Dante, Michelangelo, Wagner. Journal of Consciousness Studies, 9, p. 53-76.

\section{Referências audiovisuais}

Bonini Baraldi, Filippo (dir.). (2005). Plan séquence d'une mort criée, vídeo, cor. Legendas em francês, 62'. Prêmio "Bartok" no XXIV Festival du film ethnographique Jean Rouch, Paris. In: Écouter le monde/Around music. (Coffret de I 2 films en DVD). Paris: La Huit/Société Française d'Ethnomusicologie. Bonini Baraldi, Filippo \& Jobet, Philippe. (2013). Jouer la jale. Animação interativa. Disponível em: <http://www.ethnomusicologie.fr/tsiganes-bonini-baraldi.>. Acesso em 30 nov. 2016.

Bonini Baraldi, Filippo \& Jobet, Philippe. (2013). Lamentation funèbre. Animação interativa. Disponível em: <http://www. ethnomusicologie.fr/tsiganes-bonini-baraldi.>. Acesso em 30 nov. 2016. 


\section{COMO ESTUDAR A EMOÇÃO MUSICAL? PROPOSTAS METODOLÓGICAS A PARTIR DE PESQUISA JUNTO AOS CIGANOS DA TRANSILVÂNIA (ROMÊNIA)}

\section{Resumo}

Ainda que os etnomusicólogos não ignorem a estreita ligação da música com os processos emocionais, eles deixaram o tema de lado durante quase meio século. É duplo o objetivo deste artigo. Em primeiro lugar, serão analisadas as relações entre emoções e música em um contexto cultural bem delimitado, a saber, aquele de uma comunidade cigana da Transilvânia (Romênia). Adotamos como critério metodológico focar a atenção nos "prantos musicais", situações em que lágrimas e música caminham juntas. Foram analisados três contextos distintos de performance: a prestação de serviço profissional, as festas espontâneas e os funerais. A partir dessas descrições etnográficas, o segundo objetivo consistirá em extrapolar informações que possam ser comparadas com dados provenientes de outras sociedades. No longo prazo, esse procedimento permitirá identificar os processos psicológicos e sociais recorrentes, quiçá universais, da emoção musical.

\section{HOW TO STUDY MUSICAL EMOTION? METHODOLOGICAL PROPOSALS FROM A RESEARCH ON THE GYPSIES OF TRANSYLVANIA (ROMANIA)} tural context, namely that of a gypsy community in Transylvania (Romania). As a methodological criteria, we focused on situations in which tears and music go together. Three different performance contexts are analyzed: the provision of professional service, spontaneous parties and funerals. From these ethnographic descriptions, the second goal is to extrapolate information that can be compared with data from other societies. In the long term, this procedure will allow us to identify the recurrent, and perhaps universal, psychological and social processes of musical emotion.
Palavras-chave

Música;

Emoção;

Empatia;

Ciganos;

Romênia.

Keywords

Music;

Emotion;

Empathy;

Gypsies;

Romania. 